\title{
Challenges of Managing Risk in Small Holder Enterprises of Single Mothers in Kasoa Business District of Ghana
}

\author{
Georgina Ansong \\ Beautiful Creations Co. Ltd., Accra, Ghana \\ Email: ginasong2001@yahoo.com
}

How to cite this paper: Ansong, G. (2021). Challenges of Managing Risk in Small Holder Enterprises of Single Mothers in Kasoa Business District of Ghana. American Journal of Industrial and Business Management, 11, 804-828.

https://doi.org/10.4236/ajibm.2021.117050

Received: June 3, 2021

Accepted: July 20, 2021

Published: July 23, 2021

Copyright (อ 2021 by author(s) and Scientific Research Publishing Inc. This work is licensed under the Creative Commons Attribution International License (CC BY 4.0).

http://creativecommons.org/licenses/by/4.0/ (c) (i) Open Access

\begin{abstract}
The study set out to examine the challenges of managing risk in small holder enterprises of single mothers in Ghana with the search light on the Kasoa business district of the country. Among its objectives are examining how suitable the single mothers are in running the business of their choice, identifying any external assistance put forward to sustain their businesses as well as enumerate risk factors bedeviling their small businesses within the Kasoa enclave. In conducting the study, the researcher deemed it appropriate to employ the random sampling technique to select ten (10) brisk business areas of Kasoa where purposive sampling technique helps in identifying single mothers in those areas for their views on the objectives of the study. The interview guide constituted the main research instrument in this qualitative study while basic descriptive statistics was laced up with Statistical Packages of Social Science (SPSS) to enable analysis and interpretation to be conducted in respect of the data and information captured from the field. Findings of the study noted that single mothers of Kasoa basically wielded no formal training in the business they find themselves and that they copy other competitors strategy to operate their businesses. It also came to light that they basically start business with funds extorted by Domestic Violence and Victim Support Unit (DOVVSU) i.e. recalcitrant fathers, parents and other friends to start business in order to help themselves and their children. The study noted further that no external assistant is extended to the single mothers either from Ghana Union Traders Association (GUTA), Gender Ministry, Local government or the banks and that they are virtually on their own. It turns out unequivocally from the study that these single mothers hardly receive enough and spend all such funds to help themselves and their unfortunate children and this virtually leaves no funds to strengthen their working capital. Some even sadly resort to prostitution to solicit funds to continue business. Banks
\end{abstract}


in the area discriminate heavily against single mother traders, because they see them as high risk areas and will only help after they have provided credible records concerning their operations which are often non-existent. On risk factors, as mentioned earlier on, the ladies spend all their income on themselves and their children and therefore find it difficult to sustain their operations. This situation is exacerbated by unfair trade practices emanating from cheaper dumped goods from China which disrupt price mechanism in the area. The traders also complained of astronomically high interest rate charged by microfinance institutions which often introduce repayment leading to loan default and its concomitant of police action. Shops in the Kasoa area are so expensive that single mothers can hardly afford and for that matter they sell along the streets without any permanent trading enclaves. In the light of the challenges enumerated above, the study recommended that GUTA as a matter of urgency should liaise with the Gender Ministry, Local Government Ministry as well as other friendly NGOs not only to train and refinance the single mothers but also establish modern crèche and recreational centers for their children. In this way, the single mothers can have the peace of mind to irk a decent living and contribute effectively towards the socio-economic development of the country.

\section{Keywords}

Small Business Holders, Women Empowerment, Business Risk, Business Sustainability, Competition

\section{Introduction}

In the Africa sub-region, Sukumar et al. (2011), found out that small businesses established failed to grow up to two (2) years in South Africa. The country has the lowest thriving small business enterprises in the continent. In Ghana, 9 out of every 10 companies registered are small businesses and this sector does not only create jobs for the teaming unemployed graduates but also pay taxes to enhance government spending while offering a spring board for the youth to acquire skills as a stepping stone for irking decent living for themselves (Mensah, 2014). Small business holders also contribute significantly towards the GDP level towards developing the economy including Ghana and for that matter every effort must be made towards ensuring that the sector sustains its operations so as to continue playing its indispensable role in the socio-economic development of developing economies like Ghana.

Unfortunately, research by Mensah (2014) indicates in no uncertain terms that small businesses in Ghana are virtually left on their own with no external injections by way of concessionary loans, capacity building in financial management nor marketing. Most of them only observe what their colleagues are doing to manage their business while others understudy their family members in acquiring not too enviable skills towards running the affairs of their businesses. 
It is very common for small business holders to apply short term loans for acquiring capital projects such as flashy vehicles and landed properties which often creates serious leakages in their working capital leading to the situation where current liability cannot be paid and eventually have to hold up their operations. If small holder businesses are exposed to government influences as obtained in US and UK where small business administrators have been established to groom small businesses towards fruition, a lot more of these small business holders will not collapse within a few years of operations.

Small business holders in Ghana certainly experience serious risk of continuity, financial administration, marketing management, HR operations as well as banking operations and this often negates the fortunes of these entities. Studies abound in academia on how risk management can be averted in small business holder operations. However, these existing materials have been dominated in the Western and Asian context thereby making them unsuitable in addressing challenges facing developing economy small businesses like Ghana. This research therefore attempts to fill this gap.

\section{Objectives of the Study}

The study therefore nurses the objective of attempting to examine the challenges of managing risk in small holder enterprises of single mothers in Ghana with the searchlight on the operations of single mother traders of Kasoa business district of Ghana. Specific objectives include:

- To examine the human capital texture of single mothers in managing their small enterprises in Kasoa business district of Ghana

- To examine any external assistance put forward to enhance the sustainence of single mother enterprises in Kasoa business district of Ghana

- To identify risk factors bedevilling the operations of small enterprises in Kasoa business district

- To explore strategies for ameliorating risk factors identified with small business enterprise in Kasoa business district of Ghana as well as encourage their growth

\section{Literature Review}

This segment review contemporary articles and publications on studies involving risk management in small business enterprises in Europe (UK), America (US), Asia (India) and Africa (Nigeria and South Africa).

\subsection{Europe (UK) Experience with Risk in Small Business Holders}

In the opinion of Altman et al. (2010); Mutezo (2013); Gama and Geraldes (2012), small business holders in Europe are mainly surviving through external finance which are readily available from financial institution owing to government influences and directives. This is in sharp contrast with what prevails in Ghana where small businesses are virtually on their own and are exposed to high finance charges which often make repayment difficult resulting in huge non-performing assets. According to Mutezo (2013), in Europe, financial insti- 
tutions get involved in the operations of small holders businesses and for that matter the issue of information asymmetry is currently facing out and banks continue to have confidence in information turn out by small holder businesses for lending purposes. This again contradict what prevails in Ghana where commercial banks are only interested in granting loan and ensuring repayment but are not directly involved in their businesses and this often result in improper allocation and disbursement of short term loans contracted leading to risk of repayment default.

It also turned out that in Europe, Bruns and Fletcher (2008) explained that, small holder businesses with high operational risk are often looked down upon by some loaning outfits as they turn to be high risk areas and for that matter preference is given to those small businesses with lower risk appetite. This is reasonable because the banks operate with other peoples' money and for that matter they should ensure that investment in loan portfolios return safely with the attendant interest. Although banks in UK and Europe are prepared to take risk, small holder businesses without adequate collateral security are frowned upon and almost left out, in their loan dissipation arrangement (Bruns \& Fletcher, 2008). The study further observed that key competition, inadequate competence of competitors, varying taste in demand of customers, lack of correct market data and frequent absence of personal rate constitute essential risk factors for $\mathrm{Eu}$ ropean small business operators.

\subsection{American Context in Respect of Risk in Small Business Holders}

Studies by Vickery (2008) employed 3248 US small firms and discovered that half of them will rather go in for fixed rate finance cost rather than adjustable rate loans slated for the large firms. His studies also indicated that there were downward trends in loan acquisition as the size of the firm increased in age and size meaning that more profits might have been acquired to preempt the need for external financial help. The source also noted that small and younger companies with low cash flow and high investment opportunities often preferred fixed term loans for enhancing their operations. Vickery concluded that, small business holders are more risk averse as well as interest rate is concerned and this explains why they prefer fixed rate interest over adjustable risk loans which are often comfortable with the large scale companies. Vickery (2008) findings were earlier buttressed by Moore et al. (2000) who noted that small holder businesses could be less sophisticated in the practice of risk management than large companies and for that matter they should know that movable interest rate attract important rate of risk and for that matter they should operate in a manner that will combine both fixed rate and adjustable rate.

In the opinion of Kim and Vonortas (2014), with more education, small holder businesses in Europe are more likely to adopt essential actions in order to ameliorate financial risk involving interest rate. In their study on government abolishing deregulation of subsides in certain agricultural market, increasing 
number of small holder businesses in Europe are exploring avenues for managing the volatility in their cost of raw material so as to produce efficiently to earn decent returns despite the abolition of subsides on certain raw materials and commodities. Small businesses in Europe are also experiencing complexity in their operations owing to commodity price increases which can hardly be transferred on to the final consumer in pricing. This certainly is creating huge problems which stakeholders must help to resolve. Currently in Ghana, government has increased fuel prices by $15 \%$, import duty on spare parts has also been increased where car consumable items like engine oil, brake fluid have also all been increased. Government however, is not allowing the private road sector to increase its fares owing to the perceived repelling effect on the general prices of commodity and services leading to high cost of operations and its likely concomitant increase in demonstration over government insensitivity to plight of the people.

Furthermore Gama and Geraldes (2012) notes that owing to key competition in the industry, small holder businesses dare not increase prices of goods and services although their supply bases have been increased leading to high operation cost. Perhaps, it might be worth mentioning that not all enterprises face this problem of complexitive operations for large companies are often hooked on to the internet technology and therefore can change their supply bases thereby obtaining cheaper sources of supply and will be able to sell at prevailing competitive prices. Unfortunately, the source explains that small businesses can hardly afford to make any investments in internet technology and therefore are susceptible to the vagaries of market price risk of raw material within their various industries.

\subsection{India Experience in Respect of Managing Risk in Small Business Holders}

The concept of empowering small business holders actually begun in India owing to the huge population and the inability of government to absorb an infinitesimal percentage of the people. Various strategies were therefore put in place etc. shore up and sustain the business operations of small enterprises which were often decentralized at the grass root level. Government influence only went a long way to help grow cottage industries especially in technology and today the country is really acclaimed the best in terms of developing the small business holders to a formidable level where they contribute significantly towards the socio-economic development of the country (Scheve, 2006). The source explains further that two categories of traditional risk identified with Indian small holder businesses continue to be static risk and dynamic risk. Static risk according to Henschel (2008) constitutes those risks which bring about some kind of damages which hardly enable the entrepreneur from earning from his or her operations. Such risks are often negative and have the propensity of being unexpected because they are precipitated by events from accidents. The good news however is that such risk come under insurance policies and therefore can adequately be 
covered for indemnity.

On the other hand, dynamic risk can be certainly those risks that damage the earning opportunities of the enterprise. Mowbray and Blanchard (1979) also add that these constitute essential risk of enterprises which maintain dire consequences. Such risk can further be divided into business environment as well as internal risk. Henschel (2008) explains further that, internal risk can be financial risk, operational risk, managerial and organizational risk which all emanate from sources within the organization. The source continues that the external risk on the other hand can emanate from political, technological, legal, change of culture, taste of consumers which all combine to maintain a telling effective on the performance of the organization (Scheve, 2006). According to Halman and Weiden (1997), managing risk is essentially a continued process which ensures monitoring of integrated formal arrangement aimed at defining key objectives thereby identifying uncertainty sources for analysis of the attendant uncertainties prior to formulating and employing key resources of management to produce some kind of viable balance between opportunities and identified risk.

\subsection{Nigeria}

Like most developing economies, south of the Sahara, small business holders are virtually left on their own with very little government influence in terms of financing capacity building, marketing and sometimes infrastructure development. Notwithstanding, decentralized governance structures like the local government, municipal and district assemblies harass these traders to pick up business operating permit, daily tolls and other levies although some of the traders don't even have permanent place of operation (Gama \& Geraldes, 2012). In the opinion of Bhunia (2012), risk management in small holder businesses encapsulate all the methods or arrangement involved in ameliorating or eliminating the effect of loss or any occurrence that will worsen risk levels. The source continues that risk maintains a multitude of meaning in enterprises and occurs virtually on daily basis. He mentioned risk in terms of situation where an uncertainty about an occurrence will happen and this could be any unfortunate eventuality or a variable about something happening in respect of taking a decision about an event.

Aruwa (2004) also maintains that a risk have the probability of introducing a loss which could cause injury or huge damage that an undertaking is likely to sustain and derail its projections or targets. In the opinion of Altman et al. (2010) small business holders acknowledge the prevalence of risk and therefore put up the strategy towards effectively managing it. Kim and Vonortas (2014) also notes that, a business that does not take risk is not worth venturing in the first place and that it management at all time needs to have a plan B for attempting to derail the effect of any risk. The source identified three main stages of confronting risk of small businesses which include identifying the risk, managing it through sharing or accepting and the implementing strategies to circumvent any effect of the risk. 


\subsection{South Africa}

Studies from South Africa in relation to risk management in small holder businesses center on unreasonable high interest rate being charged by financial institution. Much earlier Stiglitz and Weiss (1981) attempted to produce a theoretical module concerning equilibrium on credit rationing which had the propensity of leveling up interest rate chargeable to the small scale sector. Others like Vickery (2008) had earlier argued that controlled interest rate will enable banks to automatically rationing credit rating using non-price means and this is likely to hurt the small business sector. Nevertheless, other school of thought maintained that, if interest rate controls were removed, imperfect information could creep in into the credit market and this has the propensity of creating risk and for that matter will render credit rationing not only suitable but also profitable for banks to increase their earning capacity. For small holder businesses to sustain their businesses, Freel (2007) pointed out that in South Africa it was agreed that the existing imperfect information on credit management ought to be maintained to enable banks apply it fairly in their credit rationing activities so as to remove any distortions that could injure sustenance of business by small scale operators. Generally, Freel (2007) is of the view that credit rationing ensues when banks customers demand more than existing loanable funds and when this happens the banks are tempted to discriminate against small businesses since they are considered higher risk areas than large scale operators. Thun et al. (2011) also confirmed the notion that the banks find way in lending to small scale enterprises owing to the high risk associated with default in repayment and for that matter if something can be done by way of stakeholders guarantying funds loan into the sector then some sanity will prevail and banks will be more than happy to doing business with all enterprises including small enterprises.

Stiglitz and Weiss (1981) are also of the view that problems with agency and information asymmetry constitute the same reason why small business holders in South Africa continue to experience serious constraints in accessing credit to revamp their operations. This is because the small sector operators hardly produce credible information concerning their operations especially profit level and this makes the banks highly skeptical and accepting financials produced from the sector in respect of loan prospecting. Generally, information asymmetry according to Hutchinson and Xavier (2006) rests on the assumption that small enterprises wield super financial reports which turn out to be untrue and therefore highly misleading. Banks which employ such incorrect financial report often note that they have been deceived and that loans contracted could experience serious repayment charges. Information asymmetry inflates profit margins and minimizes expenditure patterns and for that matter when loans are contracted and the real expenses begin to come up, the borrower then senses his limitation in respecting the tenets of the repayment schedule leading to debt rescheduling another losses to the financial institution. It is from this background that Hutchinson and Xavier (2006) notes that banks often are of the conviction that they can hardly receive credible information for effective decision making and there- 
fore loan proposals are treated with disdain. Consequently, Kim and Vonortas (2014) \& Hashi and Toci (2010) all support the notion that banks embark upon "adverse selection" in their loan investment portfolios against small holder businesses and this turn to stifle growth in the sector.

\section{Research Methodology}

This sector of the article examines the research methods employed to conduct the study on examining the risk management factors associated with small holder businesses conducted by single mothers in Kasoa. It begins by presenting the research design, followed by the study area, sample and sampling technique, instrument administration and data collection strategy as well as how information captured from the field will be analyzed for interpretation and discussion.

\subsection{Research Design}

The study segmented Kasoa into ten (10) groups or strata from which respondents were drawn for their views in strategizing the direction of the study. These areas are Nyanyanor, Budumburam, CP Area, Under Bridge, New Market, Old Market, Akweley Transformer, Amanfrom/Ngleshie and Lorry Station as well as Post Office. It can therefore be said that the study adopted the cross-sectional research design which enabled information to be obtained from various sections of the town to address the objectives of the study. This design ensures that, single mother traders living in all suburbs of Kasoa have their voices captured and analyzed for development of the study. The segmentation was predicated on the fact that starting a small business in these areas is not too difficult in terms of cost of acquiring a space to operate and therefore struggling single mothers readily move into those areas to start table top micro businesses which eventually develop into small scale and later middle level enterprises.

\subsection{Study Area}

The study took place at Kasoa one of the very fast commercial growing enclaves in Ghana. Although in terms of jurisdiction it is in the Central region of Ghana, it takes virtually 45 minute to drive to Kasoa from Accra that is the capital than to Cape Coast which the Central regional capital and about two hour drive from Cape Coast. The population census of Ghana as adjusted in 2021 puts Kasoa's population at 44,227 and with the influence of foreign nationals such as Liberians, Nigerians and Chinese, the population is expected to be more than that and this explains why business activities are soaring very high. Most commercial operators therefore procure their wares especially the assorted ones from Accra while foodstuffs, cereals, vegetables, protein items are brought from other parts of the country to Kasoa market. As a brisk commercial area, all the 23 universal banks as well as 55 savings and loans companies and numerous microfinance institutions are struggling to secure space for operation owing to the volume of trading that prevails over this area of Ghana. The town was originally founded 
by the Hausa community and therefore it is not surprising to see a lot of Muslims living in the area. Residential accommodation is also much cheaper at Kasoa and for that matter both private and public sector employees live in Kasoa while they commute daily to the capital to irk a living. The Kasoa has about 11,500 small holder businesses.

\subsection{Sample and Sampling Technique}

The study did employ the Slovin's formula for calculating minimal sample i.e. $n$ $=N /\left(1+N e^{2}\right)$, where $\mathrm{n}$ is the sample size, $\mathrm{N}$ is the population size and e i.e. the margin of error in arriving at the sample size of 200 single mother traders out of a sample frame of 4227. Kasoa is currently a cosmopolitan area and therefore the single mothers incidentally originate from almost all of the major ethnic groups in the country notably the Ewes, Fantes, Ashantis, Akuapems, the Gas, Nzema, Hausas, Dagombes, the Bonos as well as some Fulanis who all reside in the area and also irk a living in the same jurisdiction. Close to $63 \%$ of these single mothers had very little education not up to school certificate level i.e. GCE O'level and these have no vocational skills whatsoever. Sixteen (16\%) had received vocational training in dressmaking, hairdressing, catering, beads collection yet did have the means to establish themselves and for that matter entered into selling with the view to making some money for starting their various vocations. Nearly $80 \%$ of these ladies fall in the age bracket 19 and 36 years with 13\% being over $40 y e a r s$. About $3 \%$ of the ladies claimed they became single mothers as a result of some unscrupulous men raping them yet owing to their religious faith could not abort such pregnancies. The sample size of 200 was also convenient for the propagation of the study and the distribution has been indicated in Table 1.

Table 1. Distribution of respondents.

\begin{tabular}{|c|c|c|c|c|c|}
\hline Area & Population & Owner & Accountants & Total & Frequency (\%) \\
\hline Nyanyanor & 525 & 15 & 10 & 25 & 12.5 \\
\hline Budumburam & 512 & 14 & 10 & 24 & 12 \\
\hline CP Area & 380 & 11 & 7 & 18 & 9 \\
\hline Under Bridge & 450 & 13 & 8 & 21 & 10.5 \\
\hline New Market & 600 & 17 & 12 & 29 & 14.5 \\
\hline Old Market & 380 & 11 & 7 & 18 & 9 \\
\hline Akweley Transformer & 420 & 12 & 8 & 20 & 10 \\
\hline Amanfrom/Ngleshie & 380 & 11 & 7 & 19 & 9.5 \\
\hline Lorry Station & 480 & 14 & 9 & 23 & 11.5 \\
\hline Post Office & 100 & 2 & 1 & 3 & 1.5 \\
\hline Total & 4227 & 120 & 80 & 200 & 100 \\
\hline
\end{tabular}

Source: (Dr Ansong's Estimation, 2021). 


\section{Sampling Technique}

Random sampling technique was applied in selecting 10 of the 26 business areas of Kasoa where single mothers are known to operate. Purposive sampling technique helped the researcher with approaching most these girls directly to convince them towards partaking in the study. Initially, some of them was skeptical as to the rationale behind the study but the researcher employed her experience as a mother, a banker and a business advisor to convince them to partake in the study and that invariably the result of the findings could sensitize stakeholders into helping them develop and grow their businesses while making arrangement to also settle their kids in very conducive environment for their business to propagate smoothly.

\subsection{Research Instrument}

Taking cognizance that most of the single mother traders are semi-illiterates, with others no schooling experience at all, the study deemed it appropriate to employ the interview guide as the main research instrument. This was divided into four (4) parts or sections which were all devoted to issues concerning the four objectives of the study.

\subsection{Research Instrument Administration and Data Collection Strategy}

The market have queen mothers who they respect as their leaders and therefore prior to conducting the study, the researcher and her assistance paid a courtesy call on market queen mothers with drinks and explained the rationale behind the study. She pointed out that in most countries like Ghana, small businesses constitute their engine of growth and therefore it is the government's duty to create viable structures for them to grow. She mentioned the fact that the study will enumerate the risk factors of their business so as to sensitize stakeholders especially government and friendly NGOs with concessionary rate finance, training and other capacity building packages that will help them grow and contribute better to the socio-economic development of the country. With these soothing words, the queen mothers rally round all single mothers within their jurisdiction and rallied them round into groups facilitate the extraction of information. The groups were put into twelve (12) and an agreed date were fixed for the researcher to visit them to solicit the requisite information. At the appointed time, the queen mothers made sure the various groups were ready at an agreed location for Dr. Georgina Ansong and her research assistance to conduct the interview using the interview guide and other electronic equipment which recorded most the answers for later analysis, interpretation and discussions.

\subsection{Data Analysis}

As a qualitative study, basic descriptive statistics were employed in helping to analyze the data captured from the field while Statistical Packages for Social 
Science (SPSS) assisted in managing the similarity in answers for analysis, interpretation and discussions. The resulting table has been featured in the next segment of the article.

\subsection{Reliability/Viability}

Using 200 small holder traders out of 4227 i.e. 5\% to a large degree constitutes a reliable sample for generalizing the findings of the study since the traders virtually produce similar answers for most of the questions under the 4 objectives of the research. The reliability of the study sample can therefore not be in doubt. If a new set of scholars were given the opportunity to use the same research instrument to conduct this study, the researcher has no doubt in her mind that the findings will not be different from what has been reported here and for that matter the viability of the study is wholesome.

\subsection{Ethical Considerations}

Fact is that some potential respondents declined to participate in the study because they were aliens i.e. Liberians and Nigerians and therefore felt did not have the permission to trade in the small scale sector in Ghana in consonance with the laws of the land. For all such people, the study gladly excused them. Besides this, no respondent was placed under duress or coerced to answering any question that they wished not to. No sensitive questions were also posed and all answers were freely volunteered by the respondents. They were indeed assured that the study was a private one and therefore all answers were highly confidential so they should be forthright with their responses. From the foregoing it is obvious that the study was ethically upright.

\section{Findings on the Study}

Views and other indications captured from the field study have been presented in this segment of the report. It has however being arranged in-situ with the order in which the objectives have been stated in the opening chapter.

\subsection{Objective One i.e. Examining the Human Capital Level of Single Mothers in Managing Their Small Enterprises in Kasoa Business District of Ghana}

Presented hereunder are the findings in respect to objective one i.e. examining the human capital level of single mothers in managing their small enterprises in Kasoa business district of Ghana.

\subsubsection{Mode of Starting Small Business Enterprises by Kasoa Single Mothers}

Shown in Table 2 are the findings on how Kasoa single mothers start their small enterprises to enable them cater for their children.

Table 2 presents the findings on how Kasoa single mothers start their small enterprises. Ranking first with mean score of 3.67, standard deviation of 1.059 
Table 2. Frequency table showing how Kasoa single mothers start business.

\begin{tabular}{lccccc}
\hline \multicolumn{1}{c}{ Statements } & N & Mean & STD Dev & Variance & Rank \\
\hline $\begin{array}{l}\text { - Money extracted by DOVVSU } \\
\text { from baby's father/relative }\end{array}$ & 200 & 3.67 & 1.059 & 1.029 & 1 \\
$\begin{array}{l}\text { - Money volunteered by baby's } \\
\text { fathers relative }\end{array}$ & 200 & 3.61 & 1.075 & 1.037 & 2 \\
$\begin{array}{l}\text { - Money from single mother's } \\
\text { parent and family }\end{array}$ & 200 & 3.56 & 1.673 & 1.294 & 3 \\
$\begin{array}{l}\text { - Money from friendly NGOs } \\
\text { - Money from social welfare and }\end{array}$ & 200 & 3.50 & 0.971 & 0.985 & 4 \\
$\begin{array}{l}\text { government agencies } \\
\text { - Money from sympathizers on } \\
\text { radio phone-in programs }\end{array}$ & 200 & 3.50 & 1.088 & 1.043 & 5 \\
\hline
\end{tabular}

Source: (Georgina Ansong, 2021).

and variance of 1.029 was to the notion that "money extracted by DOVVSU from baby's father/relative" were used as capital in starting up the business. The second ranking with mean score of 3.61, standard deviation of 1.075 and variance of 1.037 went to the statement that "money volunteered by baby's fathers relative" helped a lot in setting up the business. The response that "money from single mother's parent and family" which also helped in financing the business came third with mean score of 3.56, standard deviation of 1.673 and variance of 1.294. Ranking fourth with mean score of 3.50, standard deviation of 0.971 and variance of 0.985 was to the idea that "money from NGOs" as liquidity in starting the business. The statement that "money from social welfare and government agencies" was used as a means of fund for commencing business came fifth with mean score of 3.50, standard deviation of 1.088 and variance of 1.043. Sometimes the nature of the delinquency on the part of the father becomes so serious that, radio stations conduct talk shows on such issues and sympathizers through in funds to support the single mother and child. This ranked sixth with mean score of 3.45, standard deviation of 0.961 and variance of 1.111 .

\subsubsection{Sustainability of Small Businesses over the Years}

Depicted in Table 3 are the findings in respect of how sustainable small businesses have been over the years in Ghana to cater for both single mother and their dependents

Table 3 presents the findings on the sustainability of small businesses over the years. Ranking first with mean score of 3.89, standard deviation of 1.046 and variance of 1.023 was to the notion that "single mother businesses operate from hand to mouth and therefore difficult to sustain operations". The second ranking with mean score of 3.61, standard deviation of 1.075 and variance of 1.037 went to the statement that "single mothers often get involved in amorous relationship to secure more funds to restart business when capital dries up". The idea that "government does not help small businesses and therefore the sector 
Table 3. Frequency table showing how sustainable small businesses have been over the years.

\begin{tabular}{|c|c|c|c|c|c|}
\hline Statements & $\mathbf{N}$ & Mean & STD Dev & Variance & Rank \\
\hline $\begin{array}{l}\text { - Single mothers businesses operate from } \\
\text { hand to mouth and therefore difficult to } \\
\text { sustain operations }\end{array}$ & 200 & 3.89 & 1.046 & 1.023 & 1 \\
\hline $\begin{array}{l}\text { - Single mothers often get involved in } \\
\text { amorous relationship to secure more funds } \\
\text { to restart business when capital dries up }\end{array}$ & 200 & 3.61 & 1.075 & 1.037 & 2 \\
\hline $\begin{array}{l}\text { - Government does not help small businesses } \\
\text { and therefore the sector face sustainability } \\
\text { challenges }\end{array}$ & 200 & 3.28 & 1.271 & 1.127 & 3 \\
\hline $\begin{array}{l}\text { Poverty alleviation NGOs influence are } \\
\text { hardly felt in Kasoa business region }\end{array}$ & 200 & 3.00 & 1.176 & 1.085 & 4 \\
\hline $\begin{array}{l}\text { - It is difficult grouping us for effective } \\
\text { management and financial assistance since } \\
\text { most of us don't have permanent places of } \\
\text { doing business }\end{array}$ & 200 & 2.94 & 1.350 & 1.162 & 5 \\
\hline $\begin{array}{l}\text { - Church groups often rally round some } \\
\text { funds to help single mothers improve their } \\
\text { working capital }\end{array}$ & 200 & 2.89 & 1.110 & 0.96 & 6 \\
\hline
\end{tabular}

Source (Georgina Ansong, 2021).

face sustainability challenges" came third with mean score of 3.28, standard deviation of 1.271 and variance of 1.127. Ranking fourth with mean score of 3.00, standard deviation of 1.176 and variance of 1.085 was to the view that "poverty alleviation NGOs influence are hardly felt in Kasoa business region". The fifth ranking with mean score of 2.94, standard deviation of 1.350 and variance of 1.162 went to the statement that "it is difficult grouping us for effective management and assistance". The benevolence of some church female groups sometimes ally round funds and look for single mothers within the locality to help beef up their working capital. This came sixth with mean score of 2.89 , standard deviation of 1.110 and variance of 0.96 .

\subsubsection{Improving Sustainability, Minimizing Risk through Training of Single Mothers}

Packaged underneath are the findings on the method of sustaining the businesses of single mothers at Kasoa business through training.

Table 4 shows the findings on the method of using training to sustain the businesses of single mothers in Kasoa business district. Ranking first with mean score of 3.710, standard deviation of 1.023 and variance of 1.046 was to the statement that "we need training in procurement matters" to help us manage our businesses. The second ranking with mean score of 3.680, standard deviation of 1.114 and variance of 1.242 went to the view that "we need training in marketing our product and services especially using ICT to increase sales". The idea that "we need training in finance and understand banking operations" came 
Table 4. Frequency table showing how sustainable small businesses have been over the years.

\begin{tabular}{|c|c|c|c|c|c|}
\hline Statements & $\mathbf{N}$ & Mean & STD Dev & Variance & Rank \\
\hline $\begin{array}{l}\text { - We need training in } \\
\text { procurement matters }\end{array}$ & 200 & 3.710 & 1.023 & 1.046 & 1 \\
\hline $\begin{array}{l}\text { We need training in marketing } \\
\text { our product and services } \\
\text { especially using ICT to increase } \\
\text { sales }\end{array}$ & 200 & 3.680 & 1.114 & 1.242 & 2 \\
\hline $\begin{array}{l}\text { - We need training in finance and } \\
\text { understand banking operations }\end{array}$ & 200 & 3.620 & 0.943 & 0.889 & 3 \\
\hline $\begin{array}{l}\text { We need training in recording } \\
\text { and turning out proper reports } \\
\text { of our operations }\end{array}$ & 200 & 3.570 & 0.984 & 0.967 & 4 \\
\hline $\begin{array}{l}\text { We need training to help us } \\
\text { bring up our children properly }\end{array}$ & 200 & 3.450 & 1.127 & 1.271 & 5 \\
\hline $\begin{array}{l}\text { We need counselling on the } \\
\text { kind of people to select as live } \\
\text { partners in order to avoid } \\
\text { mistakes again }\end{array}$ & 200 & 3.120 & 0.986 & 0.889 & 6 \\
\hline
\end{tabular}

Source (Georgina Ansong, 2021).

third with mean score of 3.620, standard deviation of 0.943 and variance of 0.889. Ranking fourth with mean score of 3.570, standard deviation of 0.984 and variance of 0.967 was to the notion that "we need training in recording and turning out proper reports of our operations". The view that "we need training to help us bring up our children properly" came fifth with mean score of 3.450, standard deviation of 1.127 and variance of 1.271. The participants also wish of get properly married and enjoy life and for that matter wants counselling on the kind of people they should select as future spouses in order not to make mistakes again. This was ranked sixth with mean score of 3.120, standard deviation of 0.986 and variance of 0.889 .

\subsection{Objective Two i.e. Examining External Assistance Put forward to Assist Single Mothers Sustain Their Businesses}

Presented in Table 5 are the findings in respect to objective 2 i.e. examining any external assistance put forward to sustain single mothers manage their enterprises in Kasoa business district of Ghana

Table 5 depicts the findings on the external assistance put forward to sustain single mothers in managing their enterprises. Ranking first with mean score of 4.11, standard deviation of 0.994 and variance of 0.988 was the idea that "government is yet to help teen mothers with funds to sustain their businesses". The second ranking with mean score of 4.09, standard deviation of 0.975 and variance of 0.951 went to the statement that "banks in the area are not interested in starting small business holders". The view that "Funds from microfinance institutions to start and continue business are so expensive and therefore repayment 
Table 5. Frequency table examining any external assistance to sustain traders.

\begin{tabular}{lccccc}
\hline \multicolumn{1}{c}{ Statements } & N & Mean & STD Dev & Variance & Rank \\
$\begin{array}{l}\text { - Government is yet to help teen mothers with } \\
\text { funds to sustain their businesses }\end{array}$ & 200 & 4.11 & 0.994 & 0.988 & 1 \\
$\begin{array}{l}\text { - Banks in the area are not interested in starting } \\
\text { small business holders }\end{array}$ & 200 & 4.09 & 0.975 & 0.951 & 2 \\
$\begin{array}{l}\text { - Funds from microfinance institutions to start } \\
\text { and continue business are so expensive and } \\
\text { therefore repayment becomes a challenge }\end{array}$ & 200 & 4.05 & 0.989 & 0.978 & 3 \\
$\begin{array}{l}\text { - GUTA is not well grounded in Kasoa and } \\
\text { therefore its influence is eligible }\end{array}$ & 200 & 4.04 & 0.962 & 0.925 & 4 \\
$\begin{array}{l}\text { - No official arrangement has been made } \\
\text { towards protecting our children in terms of } \\
\text { crèche or kindergarten while we trading }\end{array}$ & 200 & 3.95 & 0.931 & 0.867 & 5 \\
$\begin{array}{l}\text { - No noticeable NGO operations are felt in the } \\
\text { Kasoa enclave towards helping single mothers }\end{array}$ & 200 & 3.66 & 1.112 & 1.969 & 6 \\
\hline
\end{tabular}

Source (Georgina Ansong, 2021).

becomes a challenge" came third with mean score of 4.05, standard deviation of 0.989 and variance of 0.978 . Ranking fourth with mean score of 4.04, standard deviation of 0.962 and variance of 0.925 was to the response that "GUTA is not well grounded in Kasoa and therefore its influence is eligible". The statement that "no official arrangement has been made towards protecting our children in terms of crèche or kindergarten while we trading" came fifth with mean score of 3.95, standard deviation of 0.931 and variance of 0.867. In some part of Accra, friendly NGOs are helping single mothers with baby supplies as well as crèche for rehabilitating their children. Unfortunately, Kasoa is yet to benefit from this important contribution. This absence of the NGO came sixth with mean score of 3.66, standard deviation of 1.112 and variance of 1.969 .

\subsection{Objective 3 i.e. Identifying Risk Factors Associated with Single Mothers Businesses}

Captured in Table 6 are the findings on the risk factors associated with small enterprises in the district business of Kasoa.

Table 6 features the findings on risk factors associated with small enterprises in the district business of Kasoa. Ranking first with mean score of 4.09, standard deviation of 0.986 and variance of 0.973 was to the statement that "we often spend much on schooling, health and feeding our children and so it is difficult sustaining our business capital to keep our business in good shape". The second ranking with mean score of 4.07, standard deviation of 0.979 and variance of 0.958 went to the view that "there is price war in Kasoa and this disrupts trading activities leading to losses". The idea that "bank loans in respect to financial assistance are expensive and for that matter we appear to be working for the banks" came third with mean score of 4.04, standard deviation of 1.036 and variance of 1.073. Ranking fourth with mean score of 4.04, standard deviation of 
Table 6. Frequency table identifying the risk associated with small business in Kasoa.

\begin{tabular}{|c|c|c|c|c|c|}
\hline Statements & $\mathbf{N}$ & Mean & STD Dev & Variance & Rank \\
\hline $\begin{array}{l}\text { - We often spend much on schooling, } \\
\text { health and feeding our children and } \\
\text { so it is difficult sustaining our } \\
\text { business capital to keep our business } \\
\text { in good shape }\end{array}$ & 200 & 4.09 & 0.986 & 0.973 & 1 \\
\hline $\begin{array}{l}\text { - There is price war in Kasoa and this } \\
\text { disrupts trading activities leading to } \\
\text { losses }\end{array}$ & 200 & 4.07 & 0.979 & 0.958 & 2 \\
\hline $\begin{array}{l}\text { - Bank loans in respect to financial } \\
\text { assistance are expensive and for that } \\
\text { matter we appear to be working for } \\
\text { the banks }\end{array}$ & 200 & 4.04 & 1.036 & 1.073 & 3 \\
\hline $\begin{array}{l}\text { - Most of us don't have any formal } \\
\text { training in business management } \\
\text { and this is affecting our operations }\end{array}$ & 200 & 4.04 & 0.922 & 0.851 & 4 \\
\hline $\begin{array}{l}\text { - We don't have permanent places of } \\
\text { operations owing to high cost of } \\
\text { renting shops }\end{array}$ & 200 & 4.02 & 0.972 & 0.944 & 5 \\
\hline $\begin{array}{l}\text { - Although government officials i.e. } \\
\text { Municipal Assembly take daily tolls } \\
\text { from us, they don't care where we } \\
\text { operate }\end{array}$ & 200 & 3.95 & 1.111 & 0.961 & 6 \\
\hline
\end{tabular}

Source (Georgina Ansong, 2021).

0.922 and variance of 0.851 was to the statement that "most of us don't have any formal training in business management and this is affecting our operations". The fifth ranking with mean score of 4.02, standard deviation of 0.972 and variance of 0.944 went to the findings that "we don't have permanent places of operations owing to high cost of renting shops". It is surprising that government officials regularly pick up levies from these single mothers as market tolls yet no strategic plan have been put in place to get them permanent place of abode, this is highly reprehensible if not an acceptable. This finding came sixth with mean score of 3.95, standard deviation of 1.111 and variance of 0.961 .

\subsection{Objective Four i.e. Exploring Strategies for Ameliorating Risk Factors Identified}

Shown in Table 7 are the views from respondents concerning objective four i.e. exploring strategies for ameliorating risk factors identified with small business enterprise in Kasoa business district of Ghana.

Table 7 depicts the findings on exploring strategies for ameliorating risk factors identified with small business enterprise in Kasoa business district of Ghana. Ranking first with mean score of 3.96, standard deviation of 0.881 and variance of 0.776 was to the response that "GUTA must properly organize us at Kasoa so as to help us with training". The second ranking with mean score of 3.95, standard deviation of 0.891 and variance of 0.793 went to the statement 
Table 7. Frequency table on explore strategies for ameliorating risk factors in Kasoa small business enterprises.

\begin{tabular}{|c|c|c|c|c|c|}
\hline Statements & $\mathbf{N}$ & Mean & STD Dev & Variance & Rank \\
\hline $\begin{array}{l}\text { - GUTA must properly organize us at Kasoa so as } \\
\text { to help us with training and other inputs }\end{array}$ & 200 & 3.96 & 0.881 & 0.776 & 1 \\
\hline $\begin{array}{l}\text { - Government must work through GUTA with } \\
\text { funds to help sustain our businesses }\end{array}$ & 200 & 3.95 & 0.891 & 0.793 & 2 \\
\hline $\begin{array}{l}\text { - Government should provide crèche and day care } \\
\text { sectors at subsidized rate for our kids so as to } \\
\text { minimize the huge money we pay for such services } \\
\text { which damage our working capital }\end{array}$ & 200 & 3.93 & 1.152 & 1.328 & 3 \\
\hline $\begin{array}{l}\text { - Government should help us with training needs to } \\
\text { build our capacity in managing our business }\end{array}$ & 200 & 3.69 & 0.858 & 0.736 & 4 \\
\hline $\begin{array}{l}\text { - Insurance companies must consider micro } \\
\text { insurance product for us to sustain our businesses } \\
\text { and livelihood }\end{array}$ & 200 & 3.58 & 0.917 & 0.84 & 5 \\
\hline
\end{tabular}

Source (Georgina Ansong, 2021).

that "government must work through GUTA with funds to help sustain our businesses". The statement that "government should provide crèche and day care sectors at subsidized rate for our kids so as to minimize the huge money we pay for such services which damage or working capital" came third with mean score of 3.93, standard deviation of 1.152 and variance of 1.328. Ranking fourth with mean score of 3.69 , standard deviation of 0.858 and variance of 0.736 was to the idea that "government should help us with training needs to build our capacity in managing our business". The fifth ranking with mean score of 3.58, standard deviation of 0.917 and variance of 0.840 went to the notion that "insurance company must consider micro insurance product for us to sustain our businesses and livelihood".

\section{Discussion of Findings}

The study set out to examine the risk factors associated with single mothers small holder businesses at Kasoa market, one of the fast growing commercial sectors, West of Accra and the capital of Ghana. As indicated elsewhere, the brisk business in this enclave as resulted in a good number of financial institutions namely banks, savings and loans companies, microfinance companies, money lenders, funds management outlets, to compete for space to operate in the area. The popularity of the area largely emanated from the multinational texture of citizenry that is made up of Nigerians, Liberians, Malians as well as Nigeriens and of course Ghanaians. Mensah (2014) agrees with findings that owing to relatively cheaper accommodation in this area a lot more workers in Accra reside in this area and commute daily to the capital thereby putting pressure on the main four lane road connecting the two regions. Kim and Vonortas (2014) supports the findings that single mothers often start business with funds forcibly taken from their estranged husbands and relatives by appropriate gov- 
ernment agencies who arrange to pick up periodic payment for the upkeep of their abandoned children. The single mothers therefore exercise the option of investing such funds in order to register handsome returns for the upkeep of themselves and the babies.

Thun et al. (2011) are also of the view that sympathetic family members like the mother's parents and siblings usually contribute to help the single mother trade in order not to become liability on them. The source explains that some of them even go to the extent of finding suitable places for them to sell as well as influence the commodity they trade in all in the interest of the baby and the mother. The findings that some poverty alleviation NGOs like DANIDA, German GTZ, according to Wilson and Altanlar (2013) also look for such delinquent ladies and their children and act through their local agents to monitor and evaluate their trading activities. The source asks that they equip them with training as well as funding and some introduce them to packaging outlets to help them sell well packaged products in order to compete favourably within the industry. Mensah (2014) is also surprised that Central government through the social welfare department does not introduce any mechanism towards monitoring the performance of these single mothers. At least one would have expected a follow up after taking money from Domestic Violence and Victim Support Unit (DOVVSU) to be invested by the single mother, yet no such mechanisms exist and this is regrettable. The source maintains that the social welfare department ought to establish a department for ensuring that these girls and their destitute babies are carefully monitored and brought up in a way that will help them to become good citizens in the future.

Wilson and Altanlar (2013) share the finding that, periodically, the capacity of the single mothers must be built to enhance the competence and given more money to enhance the scope of their operations. This way, they would extend their business horizon, take on more hands to help reduce the teaming unemployed tertiary products within the economy. Banks are often skeptical in granting credits to small holder businesses because of asymmetry information associated with their operations, Kim and Vonortas (2014) therefore supports the findings that Central government and other stakeholders should help single mothers with accountants who will help them straighten up their financials so as to produce credible capital information to entice banks and other financial institutions to loan out funds without much observations. On the issue of caring for their children while single mothers trade, Thun et al. (2011) corroborate the findings that some crèche and recreational centers ought to be established very close to where the mothers operate so as to enable mothers have peace of minds to irk decent living and pick the children after work to their homes. Such day care centers the source explains constitute and important segment of the whole rehabilitation exercise and therefore stakeholders especially the social welfare department, friendly NGOs, Ministry Local government must collaborate to ensure that such edifices are well established and properly maintained for the well-being of the children and their mothers. 
On the issue of granting external assistance towards rehabilitating the single mothers and children, Gama and Geraldes (2012) find it difficult to understand why Central government concentrates on capital regimes and desert outskirt areas. The case on Kasoa according to Mensah (2014) cannot escape the attention of government since it is one of the most popular areas where the politicians receive votes when it comes to parliamentary and presidential elections. The source maintains that it is up to the grass root political leaders like the assemblyman and district assembly to concientize the government to use part of Ghana Education Trust Funds (GET Funds) revenue to construct such places of recreation and crèche for these unfortunate children. As indicated elsewhere owing to high risk involved, Marcelino et al. (2014) maintain that banks are not enthuse at starting up businesses especially where these young girls have virtually no experience and for that factor funds can go to waste. Banks are more interested in growing businesses rather than set them up and this is wake up call for stakeholders to help the girl child mother to set up while monitoring them to grow and leave them in the hands of the banks for study preparation.

Kim and Vonortas (2014) supports the findings that, since traditional banks are unlikely to start up single mother businesses, the only option exercisable is to go the microfinance institutions where the interest rate can be as high as $9 \%$ per month translating into over $100 \%$ per annum and this obviously kills the businesses of the single mothers since it is woefully impossible to conduct a business that will return $100 \%$ to help them repay such facilities. The single mother according to the source is therefore left in a dilemma and often worsens their plight and those not really strong reluctantly enter into prostitution to feed themselves and the children. This is certainly regrettable and the view of Gama and Geraldes (2012) must be avoided at all cost. The co-authors spoke vehemently against governments ineptitude towards such a crucial segment of the population and question the social welfare department as to why adequate arrangement are not put in place to enhance prospects in managing single mother arrangements. Mensah (2014) also laments over the fact that, in spite of the economic importance of Kasoa as an essential commercial hub of West of Accra, Ghana Union Traders association (GUTA) is yet to set up and office to help the traders over there. The source maintains that GUTA could rally round the women, put them in peer groups of twelve (12) and introduce them to financial institutions for help. This way adequate funds can be rolled out to help them purchase more, sell more, pay more taxes to strengthen government's arms and also save more to cater for themselves and their fatherless babies.

On the issue of risk factors associated with single mother small business holding operations in Kasoa, Mutezo (2013) shares the view that in most African countries single mothers are left on their own to trade and the little money made goes to the upkeep of themselves and the children and for that matter they always work from hand to mouth leaving nothing to support their working capital. The source find this regrettable and calls on African leaders to be more sympathetic for the plight of these ladies and strengthen the social welfare de- 
partment as well as grass root democratic structures to easily identify these ladies for rehabilitation. Nothing stops African government from building decent crèche and daycare centers for their children while the women are given adequate funds and monitored to do serious business with such funds. The findings that there are some kind of price war at Kasoa as a result of good dumped from Far East and sometimes nearing expiry and sold at rock bottom prices often disrupts the business activities of these single mothers who purchase their wares from reputable sources and can hardly sell at those ridiculous prices. Mensah (2014) did extensive work on this enclave and mentioned his plight among others and wondered why price control agencies neglect their statutory obligations and allow such nuisance to disrupt fair trade at Kasoa commercial enclave. The source maintains that owing to relatively few government inspecting agencies in the area, people easily troop in unlicensed and unauthorized goods in the area which are then sold at ridiculous prices to destabilize the pricing structure in the area. The source calls on relevant state organizations to be up and doing and see to it that sanity prevails and that there is fair trade within the Kasoa business district.

Another disturbing factor which has been corroborated by Poba-Nzaou et al. (2014) is the high cost of finance charge which is killing most businesses especially those of single mothers. The banks claim there is incidence of high non-performing assets at Kasoa and for that matter in arriving at interest rate, these are all factors to it leading to high cost of capital. The single mothers complain that they virtually work for the bank and therefore have little to say to care for themselves and their dependants. This is where Sukumar et al. (2011) feels government should come in, with concessionary rated funds which can be un-lend through government Mass Loan Company (MASLOC) with the single mothers put into peer groups of twelve (12) for effective monitoring and evaluation. A peer leader will always ensure that all members operate fairly with government funds and pay up as and when they fall due. Capacity building is one of the challenges bedeviling the business outlook of single mothers and this is supported by Mutezo (2013), who maintains that without conventional training in marketing, financial management, banking operations, single mothers as well as other small business holders are likely to either over trade, misuse their short-term funds, altogether mess up their businesses in the eventually fold up to worsen their plight.

According to Sukumar et al. (2011), stakeholder institutions especially the banks, social welfare department, local government, GUTA as well as friendly poverty alleviation NGOs can come together and sponsor capacity building packages at convenient periods for the single mothers and other sole traders so as to beef up their business acumen for the effective management of the business affairs. This way, procurement, sales, banking operations, marketing can all be done conventionally with the results that more revenue will be generated which can translate into better profits, pay more taxes to strengthen government 
spending and better income for themselves as well as dependents. Poba-Nzaou et al. (2014) also found out that in most parts of South-Saharan African enclaves, small business holders especially single mothers find it difficult to secure permanent place of abode to sell because of high cost of procuring shops. They therefore hawk from one place to the other and this explains why the banks are not enthusing at dealing with them. Since such people luck education to go into formal sector employment, it behoves on the local government authorities to find the places where they could comfortably stay and irk decent living. Possibly, government could find new areas and build reasonably priced shops for them to pay piecemeal over a long period of time as a way of helping them to establish as citizens and also secure their daily bread.

\section{Conclusions and Recommendations}

This segment of the report draws useful conclusions and makes appropriate recommendations based on the challenges uncovered in the study.

\subsection{Conclusion}

In the light of the information, data and others captured from the field study, it is conclusive that single mothers holding small businesses in Ghana especially in the Kasoa business district hardly wield conventional means of running their businesses and that a concerted effort must be made by stakeholders to help them with training packages in marketing, procurement, banking operations, customer care as well as people management.

It is regrettable from the study that not much external assistance have been put forward by way of finance or training to shore up the business acumen of single mothers holding small businesses in Ghana especially in the Kasoa business enclave.

Numerous risk bedevil the operations of single mothers businesses in Kasoa business enclave mainly because they sell from hand to mouth thereby spending all revenue for their upkeep and those of their descendants. Not much is left to strengthen their working capital base to sustain their businesses. This situation is exacerbated by unfair trade practices emanating from nearly expired products dumped from Far East which destabilize price mechanism in the Kasoa business enclave. Banks also discriminate seriously against single mothers in their investment in loan portfolio because they see the single mother business sector as high risk areas.

Generally, single mothers are doing good job in caring for themselves and their fatherless babies and for that matter every effort must be made to help them grow and educate their kids in the anticipated fashion. Fortunately, government has introduced free senior high school wand this will help in the proper upbringing of these children. Mothers who also have the attitude to continue education must be helped with monthly stipend to train to the best of their abilities. This way, Ghana will be leveraging on all its human capital for so- 
cio-economic development.

\subsection{Recommendation}

Based on the challenges uncovered in the study, the following recommendations are worth considering by stakeholders in order to put small holder single mother businesses in the right track towards sustaining and minimizing risk elements in their operations.

\subsubsection{Trade Union (GUTA) Must Be Present at Kasoa to Help Single Mothers}

The study noted with concern the fact that the mother umbrella of all small scale enterprises in the country i.e. Ghana Union Traders Association (GUTA) is yet to establish its presence at Kasoa market and that the single mothers are left on their own to fend for themselves. GUTA has very laudable objectives as a mouth piece for traders and often engage government on issues of taxation, reasonable port dues charges, daily levies from district assemblies and others which are also needed to help the single mothers of Kasoa market to properly irk decent living. It is hereby recommended that national executives considers as a matter of urgency establish an office at Kasoa to help these vulnerable single mothers. GUTA sometimes even guarantees government soft loans for its members and this is most needed by the single mothers at Kasoa market.

\subsubsection{Establishing Recreational Centers for Dependents at Kasoa Market} In some part of the capital city, government agencies have established daycare centers close to market places where traders lodge their kids while going about their business peacefully. Some of these centers have accredited doctors, nurses and are even fed on concessionary rated food items. It is surprising that single mothers at Kasoa are yet to benefit from this essential facility. It is hereby recommended that the local government ministry as well as Gender ministry liaise and collaborate to help Kasoa with a modern crèche and other washroom facilities that will help them in the proper upkeep of their kids while going about their trading activities peacefully. The national free school feeding project funded by the government and other world class NGOs like DANIDA can come to the aid of the single mothers at Kasoa who badly need such services. Possibly, the Catholic relieve services (CRS) and Adventist Relieve Association (ADRA) of the SDA church can be sensitized to employ part of their imported used clothing for distribution to the children.

\subsubsection{Stakeholders to Collaborate to Build the Capacity of Single Mothers Traders}

The study noted on the sad note that the single mothers had no better training in financial management, procurement, marketing, customer care nor people management and that they copy what their friends do and implement. This is not convenient enough and hereby recommended that stakeholders especially the banks, GUTA, local government, gender ministry and others to collaborate 
and organize appropriate capacity building sessions at convenient periods for the traders. To ensure total patronage, no fees should be charged but rather incentives like food and some small funds should be given to participants. Should they acquire conventional knowledge, obviously they will sell more, receive more revenue, make more profits, pay better taxes to strengthen government spending arms as well as expand their businesses to take on more employees thereby helping to reduce the bedrock of unemployed youth roaming the streets of Accra chasing non-existing jobs.

\subsubsection{Micro Insurance to Protect Single Mothers Businesses}

In recent times in Accra, almost all the major market have experienced multiples of fire outbreak leading to complete loss of capital of some traders. Government had to come in to help because insurance packages have not been arranged to cover their businesses. This is regrettable especially in modern age where awareness of insurance is expected to be high within the community. Traders are often reluctant paying insurance premiums judging from their small income and for that matter some micro insurance products must be planned for the market women under which daily payment of at least one, two or three Cedis (local currency i.e. GH\$ 1.00 equivalent to \$0.50) depending upon the traders volume of trade so as to indemnify them in the event of any fire catastrophe. Life insurance policy on similar lines can also be extended to them to cover their periods of retirement or when suddenly they become incapacitated. Some amount of compulsion must be attached to this insurance idea since government needs to be losing too much money each time fire gust markets across the country.

\section{Limitations of the Study}

Kasoa market is in the Awutu Senya East Municipal Assembly of the central region of Ghana. The area constitutes one of the 157 decentralized governance structures of the country and therefore takes cognizance of the importance of the study concerning risk management in small holder businesses. It looked as if using only Kasoa market will not come up with adequate information for addressing the aspiration of the study. Secondly, the Kasoa terrain is a difficult one and therefore it was not easy for the researcher and her assistants to meet the respondents at agreed period for conducting the study and this meant rescheduling the interaction period which delayed the original duration of the study. As a cosmopolitan, most of the semi-illiterate single mothers spoke their native languages which were difficult to translate and therefore the study had to hire translators at extra cost in order to adequately capture the information from the electronic recorders to facilitate analysis and discussion of findings. Despite these limitations, the researcher has been able to come out with a report worth sharing with academia.

\section{Acknowledgements}

The Kasoa single mother traders study will have been extremely difficult without 
the involvement of the executives of the zonal office of the Ghana Union Traders Association (GUTA). Special mention must be made of Theophilus Arhin, the zonal secretary and Edwina Mensah, the chairperson, who made available the demographic profile of female members which facilitated the selection of single mother traders towards assembling the sample frame. Anthony Koomson of the Municipal Assembly also deserves acknowledgement for providing valuable information on the operations of Kasoa market. The dedication of our uber driver, David Keelson, towards smooth provision of project's logistical support must also be commended and acknowledged.

\section{Conflicts of Interest}

The author declares no conflicts of interest regarding the publication of this paper.

\section{References}

Altman, E. I., Sabato, G., \& Wilson, N. (2010). The Value of Non-Financial Information in Small and Medium-Sized Enterprise Risk Management. Journal of Credit Risk, 6, 95-127. https://doi.org/10.21314/JCR.2010.110

Aruwa, S. A. (2004). The Business Entrepreneur. Kaduna: Development Scopy Publishers.

Bhunia, A. (2012). Association between Default Behaviors of SMEs and the Credit Facets of SMEs Owners. European Journal of Business and Management, 4, 55.

Bruns, V., \& Fletcher, M. (2008). Banks' Risk Assessment of Swedish SMEs. Venture Capital, 10, 171-194. https://doi.org/10.1080/13691060801946089

Freel, M. (2007). Are Small Innovators Credit Rationed? Small Business Economics, 28, 23-35. https://doi.org/10.1007/s11187-005-6058-6

Gama, A. P. M., \& Geraldes, H. S. A. (2012). Credit Risk Assessment and the Impact of the New Basel Capital Accord on Small and Medium-Sized Enterprises: An Empirical Analysis. Management Research Review, 35, 727-749.

https://doi.org/10.1108/01409171211247712

Halman, J. I. M., Weiden, V. D. P. M. (1997). In Search of the Best Practices in Risk Management. London: Chapman Hall.

Hashi, I., \& Toci, V. Z. (2010). Financing Constraints, Credit Rationing and Financing Obstacles: Evidence from Firm-Level Data in South Eastern Europe. Economic and Business Review, 12, 29-60.

Henschel, T. (2008). Risk Management Practice for SMEs; Evaluation and Implementation Effective Risk Management System. Berlin: Erich Schmidt.

Hutchinson, J., \& Xavier, A. (2006). Comparing the Impact of Credit Constraints on the Growth of SMEs in a Transition Country with an Established Market Economy. Small Business Economics, 27, 169-179. https://doi.org/10.1007/s11187-005-4412-3

Kim, Y., \& Vonortas, N. S. (2014). Managing Risk in the Formative Years: Evidence from Young Enterprises in Europe. Technovation, 34, 454-465. https://doi.org/10.1016/j.technovation.2014.05.004

Marcelino-Sádaba, S., Pérez-Ezcurdia, A., Echeverría Lazcano, A. M., \& Villanueva, P. (2014). Project Risk Management Methodology for Small Firms. International Journal of Project Management, 32, 327-340. https://doi.org/10.1016/j.ijproman.2013.05.009 
Mensah, S. (2014). A Review of SME Financing in Ghana. The UNIDO Regional Workshop of Financing SMEs, Accra, 2 March 2014.

Moore, J., Culver, J., \& Masterman, B. (2000). Risk Management for Middle Market Companies. Journal of Applied Corporate Finance, 12, 112-119. https://doi.org/10.1111/j.1745-6622.2000.tb00024.x

Mowbray, A. H., \& Blanchard, R. H. (1979). Insurance; Its Theory and Practice in United States. New York: McGraw Hill.

Mutezo, A. (2013). Credit Rationing and Risk Management for SMEs: The Way forward for South Africa. Corporate Ownership \& Control, 10, 153-163. https://doi.org/10.1111/j.1745-6622.2000.tb00024.x

Poba-Nzaou, P., Raymond, L., \& Fabi, B. (2014). Risk of Adopting Mission-Critical OSS Applications: An Interpretive Case Study. International Journal of Operations \& Production Management, 34, 477-512. https://doi.org/10.1108/IJOPM-03-2012-0117

Scheve (2006). Religion and Preference for Social Insurance. Journal of Politic Science, 1, 255-286. https://doi.org/10.1561/100.00005052

Stiglitz, J. E., \& Weiss, A. (1981). Credit Rationing in Markets with Imperfect Information. American Economic Review, 71, 343-410.

Sukumar, A., Edgar, D., \& Grant, K. (2011). An Investigation of e-Business Risks in UK SMEs. World Review of Entrepreneurship, Management and Sustainable Development, 7, 380-401. https://doi.org/10.1504/WREMSD.2011.042892

Thun, J. H., Drüke, M., \& Hoenig, D. (2011). Managing Uncertainty-An Empirical Analysis of Supply Chain Risk Management in Small and Medium-Sized Enterprises. International Journal of Production Research, 49, 5511-5525.

Vickery, J. (2008). How and Why Do Small Firms Manage Interest Rate Risk? Journal of Financial Economics, 87, 446-470. https://doi.org/10.1016/j.jfineco.2006.09.011

Wilson, N., \& Altanlar, A. (2013). Company Failure Prediction with Limited Information: Newly Incorporated Companies. Journal of the Operational Research Society, 65, 252-264. 